\title{
Ethnomathematics in Wedding Traditions of Dayak Ethnic
}

\author{
Hodiyanto Hodiyanto ${ }^{1,2 *}$, Karsoni Bertadinata ${ }^{3}$, Gemi Susanti ${ }^{1,4}$, Andi M. \\ Ramlan $^{1,4}$, Hartono Hartono ${ }^{2}$, Iwit Prihatin ${ }^{2}$, Utin D. Susiaty ${ }^{2}$, Muhamad \\ Firdaus $^{2}$, Darwanto Darwanto ${ }^{3}$, Sumarno Sumarno ${ }^{3}$, Agustina Marlina ${ }^{2}$ \\ ${ }^{1}$ Universitas Negeri Surabaya \\ ${ }^{2}$ IKIP PGRI Pontianak \\ ${ }^{3}$ Universitas Muhammadiyah Kotabumi Lampung \\ ${ }^{4}$ Universitas Sembilan Belas November Kolaka \\ *Corresponding author.Email: hodiyanto.21014@mhs.unesa.ac.id \& hodiyanto@ikippgriptk.ac.id
}

\begin{abstract}
The purpose of this study was to explore ethnomathematics in the Dayak Pompak'ng ethnic marriage tradition. The type of research used in this study is qualitative research with an ethnographic approach. This research was conducted on the Dayak Pompak'ng community, especially in Lintang Pelaman Village, precisely in Lintang Pelaman Hamlet, Kapuas District, Sanggau Regency, West Kalimantan Province, Indonesia. The data sources are custom leaders and mathematics teachers, and Dayak Pompak'ng people. Data collection techniques used in this study are direct observation, direct communication, and documentary techniques. Data collection tools used are observation sheets, interview guidelines, and documents. The data analysis technique used in this research is data reduction, data display and conclusion drawing/verification. The validity checking technique used is source triangulation. Based on the data analysis conducted on the findings in the field and interviews, the results of this study indicate that there are wedding traditional tools and activities that have mathematical concepts in form, use in the form of tools used, and how to use these tools. The materials in the traditional Dayak Pompak'ng ethnic game are flat shapes, Pythagorean theorem, spatial figures, calculations and sequences and series. The results showed that there was a relation between local culture and mathematics learning.
\end{abstract}

Keywords: Ethnomathematic, Marriage Tradition, Dayak Pompak'ng.

\section{INTRODUCTION}

One of the student learning processes is the development and application of mathematical concepts based on problems in everyday life [1], [2], This is also explained by [3] which states that mathematics is a human activity and mathematics must be connected with human life. The rationale of people's view that mathematics has nothing to do with everyday life and has nothing to do with culture starts from the behavior of students who do not know how to use mathematics to solve everyday problems. Thus, people do not feel the benefits of learning from mathematics.
A bridge that can connect mathematics with culture and everyday life is needed in learning mathematics, ethnomathematics [4]. D'Ambrosio explains that the purpose of ethnomathematics is to do mathematics in a different way by taking into account the development of academic knowledge of different sectors of culture and society[5].

Ethnomathematics is a new term in mathematics that links culture with mathematical concepts. This term was put forward by D'Ambrosio a Brazilian mathematician with the following definition: "Ethnomathematics is the way different cultural groups mathematise (count, measure, relate, classify, 
and infer)"[6]. According to him, ethno affixes explain all phenomena that form cultural identity which are grouped as language, codes, values, dialects, beliefs, food and clothing as well as habits and behavior. The word mathematics describes a broad view of mathematics including calculations or solving, arithmetic, classification, sorting, decision making and modeling, thus, it is necessary to show that in everyday life, people, especially students, are familiar with mathematics or mathematics is useful in everyday life. If they feel the benefits of mathematics, then automatically they will be motivated to learn mathematics.

Cultural exploration in the form of activities that contain elements of mathematics will provide new information on how diverse local Indonesian culture is. School mathematics so far only transfers knowledge without being encouraged to think critically, creatively, and reflectively on the knowledge gained [7], [8]. Ethnomathematics is a way to combine and learn ideas and methods to learn mathematical concepts [7], [9] so that students will respect each other's methods and mathematical ideas in different cultures [10]. Thus, the process will foster students' reasoning abilities, democracy, and tolerance for ideas they find during learning and outside the classroom [7], [8]. Furthermore, it is said that ethnomathematics can be used as learning that makes students love mathematics more, are motivated to learn, and be more creative through their culture [11]. Therefore, mathematics can be more easily understood [12] because it is no longer perceived as something foreign by students because it has been associated with local culture and learning mathematics can be adapted to the cultural context of students and society.

The culture that is attached to everyday life is a habit that has been ingrained with certain communities or sub-ethnicities, one of which is the custom of marriage. One of the areas, namely in Sanggau Kapuas, is one of the regencies in the province of West Kalimantan. Where the Pompak'ng Dayak Tribe is one of the many sub-tribes of the Dayak tribes who inhabit Sanggau Kapuas Regency. The Dayak Pompak'ng tribe is located between the banks of a river or beach in Sanggau Regency. The distance from Pontianak (Provincial Capital) to Sanggau district is approximately $204 \mathrm{~km}$ as shown in Figure 1. The distribution of the Pompak'ng Dayak tribe is in several villages in Sanggau Regency including Kamokng Village, Lintang Kapuas Village, Sungai Batu Village, Penyelimau Village, Lintang Pelaman Village. Each village in this sub-tribe has different wedding customs, although it is still one tribe, but the customs of each village and the equipment used in marriage are also different.

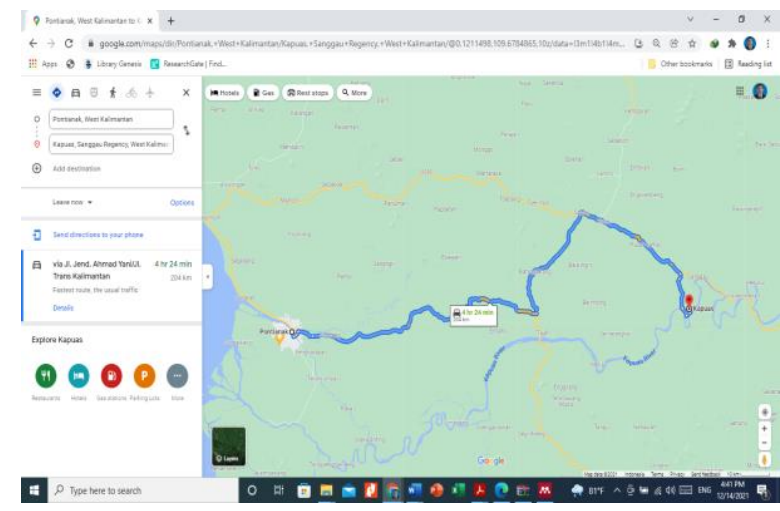

Figure 1 Location of Sanggau Regency on maps

Lintang Pelaman Village has its own customs and traditions as well as the wedding tools used, one of which is Par, its function is to store Probaya open materials used for traditional wedding events. The surface of Par resembles a circle if the top is seen as a whole like a half ball while the legs of Par resemble a cone, as shown in Figure 2.

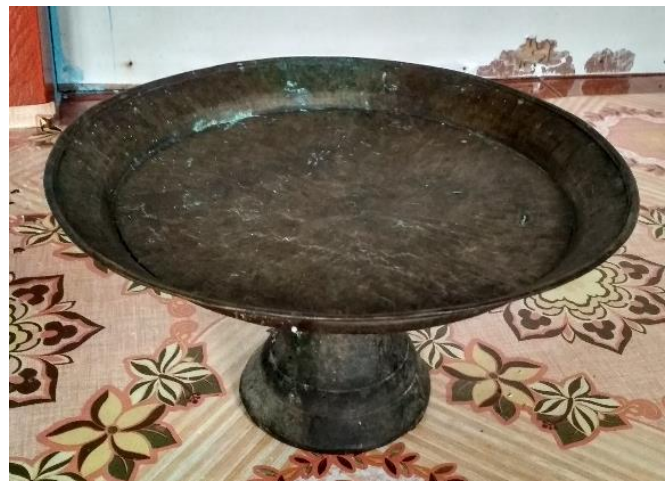

Figure 2 Par from the front and from above

Therefore, there are many more tools and traditions in marriage customs which are certainly related to mathematics, but the researcher tries to introduce the traditional tools of the Dayak Pompank'ng marriage in relation to mathematics. The results research shows that the saprahan tradition of the Malays in Sambas Regency contains mathematical concepts both in their saprahan activities and the media/tools used when the saprahan tradition is carried out [13]. Therefore, it is necessary to continue to explore ethnomathematics in culture or traditions in West Kalimantan, especially in Dayak culture. 


\section{METHODS}

The method used was a qualitative method with an ethnographic approach. Ethnographic research involved learning activities about the world of people who have learned to see, hear, speak, think, and act in different ways. So ethnography does not only study society, but more than that, ethnography learns from society [14].

This research was conducted on the Dayak Pompak'ng ethnic community, especially in Lintang Pelaman Village, precisely in Lintang Pelaman Hamlet which is in Kapuas District, Sanggau Regency, West Kalimantan Province. Data sources were traditional leaders, mathematics teachers and people of the Dayak Pompak'ng.

Data collection techniques was the most important step in research because the main purpose of research was to obtain data. The data collection techniques used in this research were: (1) direct observation, (2) direct communication, (3) documentary technique. The main instrument in this research was the research itself or the human instrument. In qualitative research, the main instrument was the researcher himself. Supporting data collection tools in accordance with these techniques are: (1) Observation sheets, (2) Interview guidelines, (3) Documents. To test the validity of the data, researchers used the Triangulation technique, precisely Source Triangulation. Source triangulation is to test the credibility of the data by checking the data that has been obtained through the source [15]. The data analysis technique used in this research is qualitative data analysis technique of Miles and Huberman: data reduction, data display and conclusion drawing/verification [15].

\section{RESULTS AND DISCUSSION}

\subsection{Results}

Based on the information obtained from all informants, there are several traditional tools of the Dayak Pomppak'ng ethnic wedding tradition, namely par, bowl sangkal, gong, tudung probaya, nails, serampang, lotos, small takin, copan, talam, crock, bamboo, and mat. pillow mats rolled into one. From this information, there are several tools that are currently not used or have become extinct, and some tools are almost extinct due to the influence of modern culture, there are fourteen traditional wedding tools found in the wedding tradition of the Dayak Pompak'ng tribe. The following is an explanation of the tools that still exist or are used in the wedding tradition of the Pompak'ng Dayak tribe.

\subsubsection{Tools used in the Pomppak'ng Dayak wedding}

Par

Figure 3 Par

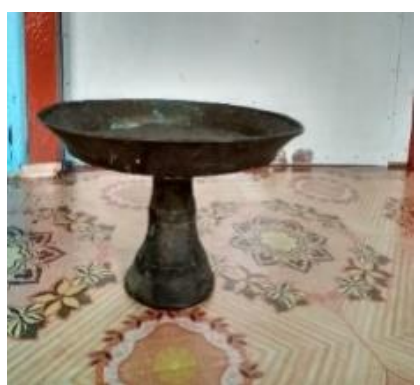

Par is one of the tools used in the traditional Dayak Pompak'ng wedding tradition. Par is made of copper and has been used for generations since ancient times. Par is also used to store Probaya ingredients used for traditional wedding ceremonies. Par when viewed from the base surface is circular and there is a cone that is cut off at the foot of par. The mathematical concepts included are included in the spatial and flat shapes.

\section{Sangkal Bowl}

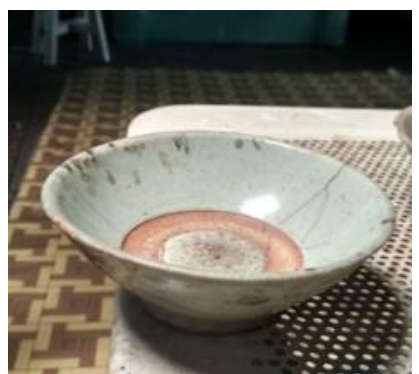

Figure 4 Sangkal Bowl

Sangkal bowl is a tool used in the traditional Dayak Pompak'ng wedding tradition. The function of this sangkal bowl itself is to store the ingredients that will be used in the probaya breaking event, the peak event in the traditional Dayak Pompak'ng wedding tradition. Sangkal bowl, if interpreted according to tradition, the bride and groom who divorces will be subject to customary sanctions. The bowl of denial is also used as a measure of error in accordance with applicable customary law. The bowl denies when viewed from a circular surface, the mathematical concepts contained are included in a flat shape. 


\section{Tudung probaya}

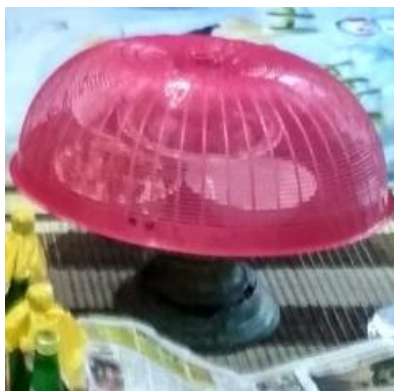

Figure 5 Tudung probaya

Tudung probaya is one of the tools used in the traditional wedding tradition, the function of this hood is to cover the probaya materials stored above par. This Tudung probaya will be opened when the event reaches the peak of this traditional wedding, which is called Buka Probaya. If you look at the Tudung probaya in the shape of a hemisphere, the mathematical concepts included are included in the spatial structure.

\section{Gong}

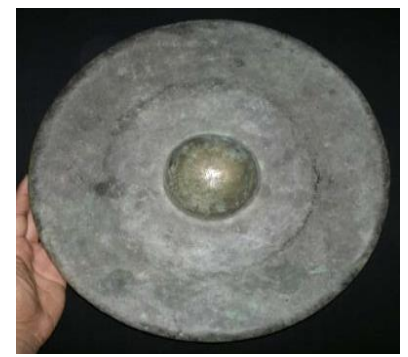

\section{Figure 6 Gong}

Gong is also a tool used to call all villagers to come to the place of the person holding the traditional wedding at home. Gong is also used when explaining customs to the bride or groom. The shape of a circle if you look at it from the surface, but if you look at it again, the gong has a space inside and is in the shape of a hemisphere, the mathematical concepts contained are included in the shape of the space and the shape is flat.

\section{Serampang}

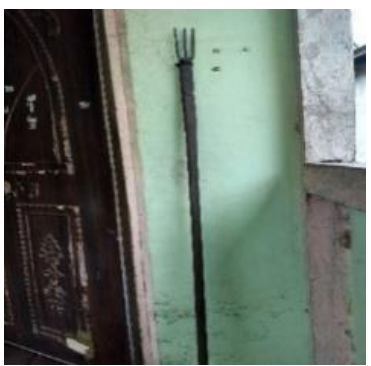

Figure 7 Serampang

This serampang, if explained traditionally, is used to protect oneself from all wild animals and is also used to look for side dishes. The stalk is rectangular in shape.

\section{Lotos}

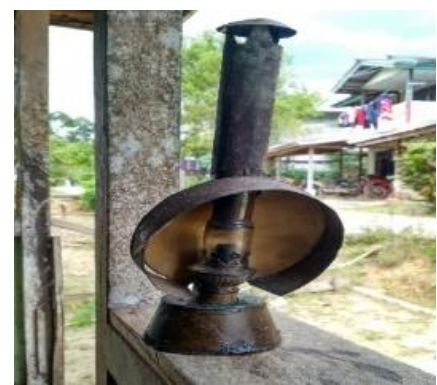

Figure 8 Lotos

Lotos if interpreted traditionally to illuminate the path of the bride and groom. Lotos were also used by the indigenous Dayak Pompak'ng people to illuminate when hunting and fishing. The lid of the lotos funnel is in the shape of a cone, the lotos funnel is in the form of a tube, the center of the guard is circular, and the feet of the funnel are truncated in the shape of a cone, mathematical concepts that are included in spatial and flat shapes.

\section{Takin}

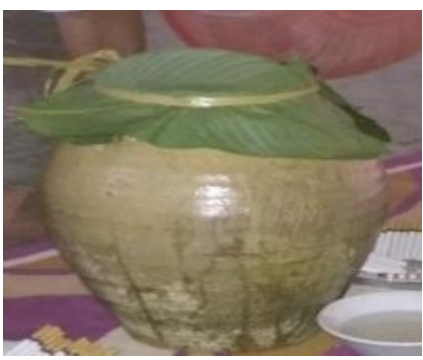

Figure 9 Takin

Takin is used to store game and vegetables obtained from fields and forests. This takin is made of rattan and made by weaving. It is tubular in shape and 
has a circle-shaped woven cover, mathematical concepts that are included in spatial and flat shapes.

\section{Copan}

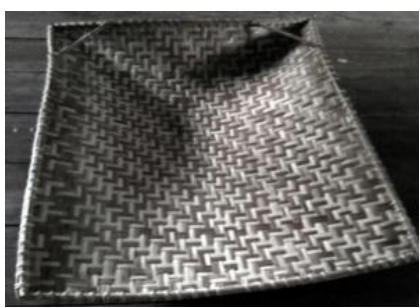

Figure 10 Copan

If explained by custom, this Copan marriage is used to store the sanbisan ingredients that will be given to the bisan from the host. Copan in everyday life is used as a repellant for freshly milled rice to separate the rice from the remaining pulp. Copan is rectangular in shape and forms a right triangle with an imperfect $90^{\circ}$ angle, a mathematical concept that is included in the plane and angle shapes.

\section{Talam}

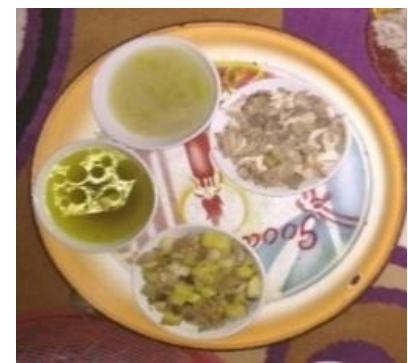

Figure 11 Talam

Talam has the same function and use as par, but the tray is used if the host doesn't have par, so this tray serves par. The tray is circular if you look at the surface, the mathematical concepts contained are included in a flat shape.

\section{Okang}

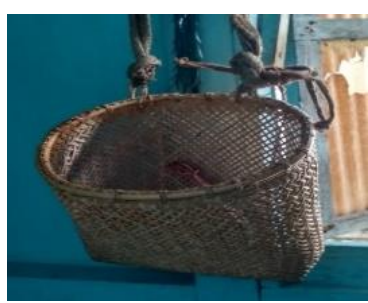

Figure 12. Okang

Okang is another name for a crock used as a probaya palm wine store. The okang lid will be opened after the end of the probaya breaking event and the wine in it is distributed to the public. Ok, if you look at it from a circular surface, the mathematical concepts contained are included in a flat shape.

\subsubsection{Wedding Tradition Activities

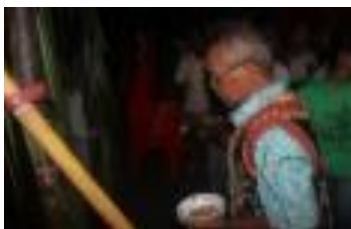

Figure 13 Bepomang Ritual Activities

Bepomang ritual activities are carried out at the time of welcoming the pongabang or the guests of the bride and groom. This ritual activity is carried out by sprinkling rice on the pongabang seven times and praying. The mathematical concept contained in it is Numbering. Saying in the Dayak Pompak'ng language is shown in the table below.

Table 1 Numbering in the Dayak Pompak'ng ethnic culture Numbering

\begin{tabular}{|l|l|l|}
\hline No & $\begin{array}{l}\text { Terms used in the Dayak } \\
\text { Pompak'ng } \\
\text { community }\end{array}$ & $\begin{array}{l}\text { Terms in formal } \\
\text { mathematics }\end{array}$ \\
\hline 1 & Kitek & One \\
\hline 2 & Dukah & Two \\
\hline 3 & Tarroh & Three \\
\hline 4 & Mpat & Four \\
\hline 5 & Rimuh & Five \\
\hline 6 & Nuum & Six \\
\hline 7 & lju & Seven \\
\hline
\end{tabular}

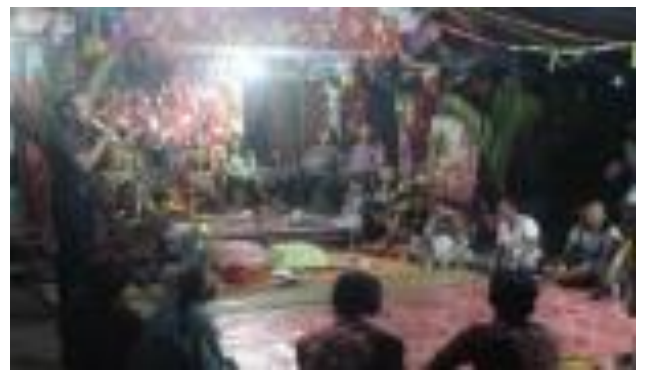

Figure 14. Nomar probaya (inaugurate the bride or groom

Nomar probaya is the culmination of the traditional wedding of the Dayak Pompak'ng ethnic group. At the time of the probaya nomar event, there were also 
conveyed about the customary law of marriage, the benchmark being the bowl of denial, if someone divorced between a man and a woman, for example, a sanction or punishment of 3 taels was the same as 24 trespasses or 24 bowls if converted into money. The amount is Rp. 1,350,000 and also during the customary explanation of each dish meaning, the gong is struck seven times to indicate that the adat explanation has been conveyed. The mathematical concepts contained in it are Numbering and Calculation.

Based on this cultural form, there are traditional tools for the traditional Dayak Pompak'ng wedding which can be used as a tool to support learning in schools and there are also mathematical activities in the traditional Dayak Pompak'ng wedding tradition. Traditional tools that can be adopted into mathematics learning related to measurement and area are summarized into one material, namely geometry, which is par which has a shape resembling a circle and there is a cone cut off from the leg of par, a bowl of denial which has a circular shape and is used as a legal benchmark. customs that are included in the calculation material, the probaya hood which has a shape resembling a half ball, the gong which has a circular shape on the surface and a half ball inside, the okang (jar) has a circular shape on the surface, the serampang has a rectangular shape, lotos has a shape consisting of form a tube space, the cone is cut off at the foot, the cone is above the lotos funnel and is a flat circular shape, the takin has a shape resembling a tube and a circle, the copan which has a rectangular shape and has a right triangle with an imperfect $90^{\circ}$ angle, the tray which has base shape circle surface.

\subsection{Discussion}

The results of the study show that the mathematical concept exists in the tradition of Dayak marriage, both in traditional tools and in bepomang ritual activities.

\subsubsection{Ethnomathematics on traditional tools in Dayak Pompak'ng ethnic marriage tradition}

The results of the exploration of mathematical elements in Dayak Pompak'ng wedding tools show that there is a mathematical concept in Dayak traditional wedding instruments. The complete summary can be seen in Table 2 below.
Table 2 Mathematical concepts and their applications in Dayak Pompak'ng wedding tools

\begin{tabular}{|c|c|c|}
\hline No & $\begin{array}{c}\text { Mathematical } \\
\text { Concepts }\end{array}$ & $\begin{array}{c}\text { Dayak Pompak'ng } \\
\text { wedding traditions }\end{array}$ \\
\hline 1 & Circle & $\begin{array}{c}\text { Par, Gong, Sangkal } \\
\text { bowl, Lotos, Talam, } \\
\text { Takin and Okang }\end{array}$ \\
\hline 2 & Rectangles & $\begin{array}{c}\text { Serampang dan } \\
\text { Copan }\end{array}$ \\
\hline 3 & $\begin{array}{c}\text { Beheaded } \\
\text { Cones }\end{array}$ & Par dan Lotos \\
\hline 4 & Half Ball & $\begin{array}{c}\text { Gong dan Tudung } \\
\text { Probaya }\end{array}$ \\
\hline 5 & Tubes & Lotos \\
\hline
\end{tabular}

Based on Table 2, it indicates that the mathematical concepts in traditional tools in general are the application of the concepts of geometry, be it flat geometry or spatial geometry. The interesting thing about this finding is that in teaching geometric concepts, whether it's a circle, a rectangle, a truncated cone, a half sphere, and a cylinder, you can use these findings as a starting point in teaching these concepts. Teaching mathematics with a cultural starting point attached to students makes them understand the material faster and make fewer mistakes [16]-[18].

\subsubsection{Ritual activities in Dayak Pompak'ng ethnic marriage tradition}

In addition to the traditional tools in traditional weddings that can be used as a support for learning at school, there are also ritual activities carried out by the Dayak Pompak'ng tribe in the traditional wedding tradition. According to interviews that have been conducted, there are ritual activities, namely besipoh or pomang. The pomang ceremony is carried out at the time of welcoming the pongabang at the foot of the stairs or the front porch of the house by sprinkling rice to the guests or pongabang seven times, this pomang ceremony means praying and this ceremony is rarely used anymore unless someone can do it because not just anyone can doing this pomang, if it is included in learning mathematics, it is included in the material for counting and probaya nobar activities in which there is a customary explanation that explains the customary law of marriage, the benchmark is the bowl of denial, if there is a divorce between the man and woman, for example, it is imposed a sanction or penalty of 3 taels is equal to 24 cassava or 24 bowls if converted into money, the amount is Rp. 1,350,000.00 and when the customary explanation of each meaning of the dish is delivered, the gong is struck seven times to indicate that the adat explanation has been conveyed, the mathematics lessons contained in it are counting and calculating. 
The results of this study indicate that there are tools and activities of the Dayak pompak'ng wedding tradition that contain elements of mathematics. This finding is supported by the results of Dominikus' research which says that there are tools and activities in traditional marriages that contain elements of mathematics [19], [20]. Thus, these findings support previous findings that have been carried out by Dominic's research [19], [20]. This finding will also help educators to utilize ethnomathematics in the learning process so that students more easily understand the mathematical concepts to be taught. Ethnomathematics is related to local culture which contains elements of mathematics and is often encountered by students so that through media or activities that are often encountered by students will help and make it easier for them to understand mathematical concepts. To make it easier for educators to use ethnomathematics, researchers make books that can be used in the learning process. The ethnomathematics book made can be useful for teachers as a learning medium in schools to introduce students that in community cultural activities there are many mathematical concepts, one of which is in the traditional marriage tradition, so that students' understanding of a material is easier because it is directly related to their culture which is an activity. everyday life in society. The application of ethnomathematics in learning mathematics is one of the ways that teachers can innovate learning in the classroom and efforts to improve the quality of learning mathematics, on the other hand the teacher directs students to get to know the existing culture better.

\section{CONCLUSION}

Based on the results of research and discussion of the traditional tools of the Dayak Pompak'ng ethnic marriage tradition in learning mathematics in schools, it can be concluded in general that the traditional tools of the Dayak Pompak'ng ethnic wedding tradition can be used in learning mathematics in schools, as for the conclusions that have been drawn. detailed as follows: (1) The traditional tools of the Dayak Pompak'ng ethnic marriage tradition that can be used in learning mathematics in schools are par, bowl sangkal, okang, takin, serampang, lotos, talam, tudung probaya, gong, copan, and bamboo tuak somang. Mathematics that can use the traditional tools of the Dayak Pompak'ng ethnic wedding tradition are, wake up flat, build space, and calculation. (2) There are two activities in the Dayak Pompak'ng ethnic wedding tradition that contain mathematical elements, including the ritual activity of Bepomang, which contains the mathematical concept of Numbering and the Nobar Probaya activity, which contains the mathematical concept of calculation when conveying about customary law and counting at the time of beating the gong.

\section{REFERENCES}

[1] B. Tanujaya, R. Prahmana, and J. Mumu, "Mathematics instruction, problems, challenges, and opportunities: A case study in Manokwari regency, Indonesia,” 2017.

[2] Risnawati, Z. Amir, and D. Wahyuningsih, "The Development of Educational Game as Instructional Media to Facilitate Students' Capabilities in Mathematical Problem Solving," J. Phys. Conf. Ser., vol. 1028, no. 1, pp. $\quad 0-7, \quad 2018$, doi: 10.1088/17426596/1028/1/012130.

[3] H. Freudenthal, Revisiting mathematics education: China lectures, vol. 9. Springer Science \& Business Media, 2006.

[4] I. Abdullah, "Dekonstruksi Komunitas: Dari Homogenitas Nilai ke Diferensiasi Praktik Sosial," Dalam Konstr. dan Reproduksi Kebudayaan. Yogyakarta Pustaka Pelajar, 2006.

[5] U. d'Ambrosio, "Ethnomathematics and its place in the history and pedagogy of mathematics," Learn. Math., vol. 5, no. 1, pp. 44-48, 1985.

[6] U. D'Ambrosio, "Ethnomathematics: A research program on the history and philosophy of mathematics with pedagogical implications," Not. Am. Math. Soc., vol. 39, no. 10 , pp. 1183-1185, 1992.

[7] U. D'Ambrosio, "An Overview of the History of Ethnomathematics," 2016.

[8] I. Risdiyanti and R. C. I. Prahmana, "The Learning Trajectory of Number Pattern Learning Using" Barathayudha" War Stories and Uno Stacko.," J. Math. Educ., vol. 11, no. 1, pp. 157-166, 2020.

[9] M. Rosa et al., Current and future perspectives of ethnomathematics as a program. Springer Nature, 2016.

[10] U. D'Ambrosio, "Ethnomathematics and its Place in the History and Pedagogy of Mathematics.," Learn. Math., 1985.

[11] R. C. I. Prahmana and A. Istiandaru, "Learning sets theory using shadow puppet: A study of javanese ethnomathematics," Mathematics, vol. 9, no. 22, 2021, doi: 10.3390/math9222938. 
[12] S. Mania and S. Alam, “Teachers' Perception toward the Use of Ethnomathematics Approach in Teaching Math.," Int. J. Educ. Math. Sci. Technol., vol. 9, no. 2, pp. 282-298, 2021.

[13] M. Firdaus and H. Hodiyanto, "Eksplorasi Etnomatematika Islami pada Tradisi Makan Besaprah," AKSIOMA J. Progr. Stud. Pendidik. Mat., 2019, doi: 10.24127/ajpm.v8i3.2385.

[14] J. P. Spradley, The ethnographic interview. Waveland Press, 2016.

[15] P. D. Sugiyono, metode penelitian kuantitatif, kualitatif,dan R\&D. 2016.

[16] R. A. S. Matang and K. Owens, "The role of indigenous traditional counting systems in children, $\mathrm{s}$ development of numerical cognition : results from a study in Papua New Guinea," 2014, doi: 10.1007/s13394-0130115-2.

[17] R. C. I. Prahmana and U. D'Ambrosio, "Learning geometry and values from patterns: Ethnomathematics on the batik patterns of yogyakarta, indonesia," J. Math. Educ., vol. 11, no. 3, pp. 439-456, 2020, doi: 10.22342/jme.11.3.12949.439-456.

[18] R. Eglash, A. Bennett, C. O’donnell, S. Jennings, And M. Cintorino, "Culturally Situated Design Tools: Ethnocomputing from Field Site to Classroom," Am. Anthropol., vol. 108, no. 2, pp. 347-362, 2006, doi: 10.1525/aa.2006.108.2.347.

[19] W. S. Dominikus and T. Nusantara, "Subanji, \& Muksar, M.(2016). Link Betweeen, Ethomatematics in Marriage Tradition in Adonara Island and School Mathematics," IOSR J. Res. Method Educ., vol. 6, no. 3, pp. 56-62.

[20] M. Dominikus, W.S, Nusantara, T., Subanji, \& Muksar, "Ethomatematics in Marriage Tradition in Adonara Island East Flores," 2016, pp. 269-274. 